Hypotheses

\title{
A Comparison of Price Effect and Country of Origin Effect on Consumer Counterfeit Products Purchase
}

\author{
Martin Owusu Ansah \\ Department of Management, Rhodes University, P. O. Box 94, Grahamstown - South Africa
}

\section{Article history}

Received: 17-02-2017

Revised: 22-08-2017

Accepted: 9-11-2017

Corresponding Author: Email: owusumartin97@yahoo.co.uk

\begin{abstract}
Proliferation of Counterfeit Consumer Products is one of the insistent apprehensions confronting managers and companies in many countries. The current study compared the influence of price and country of origin effects on consumer attitude and purchase intention of counterfeit consumer products in the Kumasi Metropolis of Ghana. The study adopted a positivist research philosophy and a descriptive research design in gathering and analysing the data. A total of 265 respondents was sampled for the study. A Statistical Package for Social Sciences (SPSS) was employed using T - Test statistic as well as the Kruskal - Wallis test in cross examining the demographic features and the study's variables. Structural Equation Modelling statistical (SEM) technique using Partial Least Square (PLS) software version 3.0 was employed in determining the hypothesised relationships of the study. It was observed that, country of origin effect has a superior influence on both consumer attitude and purchase intention than price of the counterfeit products. The results also showed a significant association between level of education and consumer counterfeit products purchased. The findings contribute to the scant empirical studies that compare price factor and country of origin effect on attitude and intention to purchase in a single survey research.
\end{abstract}

Keywords: Country of Origin, Price, Counterfeit

\section{Introduction}

Activities of counterfeiting appear to be growing at a more rapid speed than ever (Wilcox et al., 2009) in spite of governments, law - enforcement agencies as well as organisations using considerable resources in tackling them. The practice has become a serious worldwide predicament in its own right - in the past three decades (Bian and Moutinho, 2011). Such an occurrence has become very complicated to control - especially in the consumer market (Sahin and Atilgan, 2011). According to the International Anti-Counterfeiting Coalition (IACC, 2014), the projected cost of international trade on counterfeiting in 2015 stood at $\$ 1.77$ trillion. Counterfeiting has been contributing towards a loss of 300,000 jobs in Europe each year (Eisend and SchuchertGuler, 2006). According to Stumpf and Chaudhry (2011), understanding the root of consumers' involvement in buying counterfeit products is sternly social, economic and opinionated sticky situation. Consumers purchase counterfeit products with the notion that, the utility and benefits of the original product is the same as what they purchase coupled with cheaper prices (Klaus-Peter et al., 2012). Chaoa (1998); Jaffe and
Nebenzahl (2001) all observed that, customers and consumers inclined to oversimplify the value of all products from one country to the other; such that, countries that are professed positively to specific product's quality tend to have premiums (Nebenzahl and Jaffe, 1996). With strong effect even on consumer markets (Roth and Diamantopoulos, 2009).

Previous research on counterfeiting mainly centred on the supply factors (Bamossy and Scammon, 1985),which afterwards shifted to the demand factors (Nia and Zaichowsky, 2000; Wilcox et al., 2009). Even though, studies highlighted on price and value towards the appreciation of purchasing behaviour of counterfeits (Cordell et al., 1996; Harvey and Walls, 2003; Poddar et al., 2012). The avowal regarding price and value as some of the reasons for counterfeit purchase was refuted by Phau et al. (2009; Bian and Moutinho, 2009; Han et al., 2010; Eisend and Schuchert-Guler, 2006:14); who all opined that, financial incentive was not purely a substantiation liable for the conscious purchase of counterfeit products. Phau and Teah (2009; Tang et al., 2014) revealed that, country of origin effects have manifestations on consumers' purchase of counterfeit 
products. According to Poddar et al. (2012), numerous calls have been made by researchers to move beyond purely economic antecedents in assessing counterfeiting from the consumer perspective. It is again acknowledged that, previous studies on counterfeiting activities have been conducted in developed economies (Eisend and Schuchert-Guler, 2006; Staake et al., 2009). According to Nwankwo et al. (2014; Bian et al., 2015; Stöttinger and Penz (2015), various studies have examined the demand side of counterfeiting products - addressing a multiplicity of conceivable causes of consumer counterfeit purchase decisions.

According to Jiang and Cova (2012), there are five groupings of elements that compel both consumers and customers to purchase counterfeit products. The initial type relied on product characteristics which comprised: Price (Poddar et al., 2012), risk in investment (Cordell et al., 1996); product utility (Tang et al., 2014), product attributes, and style (Bloch et al., 1993). The second grouping was on consumers' demographic and psychographic variables: social status (Bian et al., 2015), counterfeit purchase involvement (Stöttinger and Penz, 2015) and attitudes towards counterfeit purchases (Chen et al., 2015). The third grouping relied on the social and cultural situations such as cultural norms (Lai and Zaichkowsky, 1999), country of origin, social influence (Phau and Teah, 2009; Tang et al., 2014) and ethnocentrism (Chakraborty et al., 1996). The fourth grouping comprised mood and situational environment such as authentic experience (Gentry et al., 2001) while the final grouping comprised the consumers' ethical and legality cues such as legal protection of intellectual property (Chiu and Leng, 2016), toeing the law line and ethical standards (Phau et al., 2009). According to Harvey and Walls (2003; Poddar et al., 2012), price determinant is seen as one of the reasons consumers purchase counterfeit products while other authors have also observed that, country of origin effect was one of the major reasons behind the purchase of counterfeit (Tang et al., 2014). There is a mounting empirical confirmation that, Country of Origin (COO) and price are influential predictors of product evaluations (Insch and McBride, 2004) as well as purchasing decisions (Awada and Yiannaka, 2012; Godey et al., 2012). A study by Chia-Lin et al. (2017) is one of the latest research works on the consequence of $\mathrm{COO}$ and price sensitivity in elucidating customer purchase behaviors in the purchase of skin products in Taiwan.

Nevertheless, limited researchers have combined and compared price factor and country of origin factor towards the assessment of counterfeit consumer product purchase in the same studies (Ansah, 2017). This study aims to fill that gap in the extant literature by comparing the strength of both price and country of origin effects on counterfeit consumer purchases so as to add knowledge to literature, practice and policy initiatives in fighting counterfeiting in the sub - Saharan Africa. Ghana as a developing country in Africa has been battling with counterfeiting activities; whose roots are difficult to identify and eradicate. Considering the scant nature of studies on counterfeit - comparing price and country of origin effect in the purchase of counterfeit products in Africa coupled with the limited studies on nondeceptive counterfeiting activities in the literature necessitated the current study.

\section{Objectives of the Study}

The objectives of the study are to:

1. Examine the relationship between price and intention towards counterfeit purchase in the Kumasi Metropolis

2. Analyse the influence of price on attitude towards counterfeit purchase in the Kumasi metropolis

3. Determine the impact of country of origin effects on attitude towards counterfeit purchase in the Kumasi metropolis

4. Establish the association between country of origin effect and purchase intention of consumers in the Kumasi metropolis

5. Examine the relationship between attitude towards counterfeit purchases and purchase intention of consumers in the Kumasi metropolis

\section{Hypothesis Statement:}

H1: There is a significant positive relationship between price of counterfeit products and purchase intention towards counterfeit in Ghana

H2: There is a significant positive relationship between price and attitude towards counterfeit purchase in Ghana

H3: There is a significant positive relationship between country of origin effect and attitude towards counterfeit purchases in Ghana

H4: There is a significant positive relationship between country of origin effect and purchase intention

H5: There is a significant positive relationship between attitude towards counterfeit purchases in Ghana and purchase intention

\section{Hypothesis Development}

The development of the study's hypotheses are presented below:

\section{Price and Purchase Intention}

Counterfeiting is calculatingly made to lure consumers in purchasing products by making prices much cheaper and very economical. Phau et al. (2009) observed that, prices of cheaper counterfeit products have considerable consequences on consumers' purchase intentions. Perceived affordability, according 
to Cheng et al. (2011: 278) has become a motivator of counterfeit procuring in spite of whether the product is costly or reasonably priced. Rutter and Bryce (2008: 1156) acknowledged price as the leading inspiration towards the purchase of counterfeit goods. It simply explains that, the price tags on consumer counterfeit products have a greater influence on consumers' intention to make a purchase. Drawing from the forgoing debate and empirical evidence, the study hypothesises that:

H1: Price has a significant positive influence on consumer purchase intention towards counterfeit products

\section{Price and Attitude towards Counterfeit Purchase}

Price benefit of counterfeit to unadulterated product is one of the major reasons for consumers' demand for counterfeit products (Stoethinger and Penz, 2015). According to Cheng et al. (2011: 279), the professed affordability on the part of consumers has become an impulsion on their attitude towards the purchase of counterfeit products. Cheaper prices are a vital determinant in promoting the demand for counterfeit products (Harvey and Walls, 2003). According to a study by Bloch et al. (1993:31), people purchase counterfeit products because they get benefit at the exclusion of payment. Based on the evidence from the literature, the study posits that:

H2: Price has a significant positive relationship on attitude towards counterfeit purchases

\section{Country of Origin Effects and Attitude}

According to Mitchell and Olson (1981) the feeling of a consumer has an internal assessment toward a product purchase. Studies have shown that consumers use products' country of origin effect as a power over their attitudes towards making purchases (Knight and Calantone 2000; Laroche et al., 2005). Country of origin effect has become one of the influences on consumers' attitude towards products. It therefore makes it clear that, when a consumer cognitively thought of quality associated with a particular country - such a consumer is more probable to shape an assenting attitude towards the purchase of that product. Accordingly, the study then posits that:

H3: Country of origin effects have a significant positive relationship with attitude towards counterfeit purchases

\section{Country of Origin Effects and Purchase Intention}

According to Lee (2005) many studies have been carried out on country of origin effects towards the behaviour of consumers. Country of origin of a product has a greater control on consumer purchase intention (Zeugner-Roth and Diamantopoulos, 2010).
The effect has seen to have gotten a greater control over purchase intentions (Lin and Chen, 2006; Ghazali et al., 2008; Rezvani et al., 2012). The study therefore hypothesises that:

H4: Country of origin effect has a significant positive relationship with consumers' intention to make a purchase

\section{Attitudes and Purchase Intention}

Attitudes are established dispositions - which are not liable to change under everyday circumstances. According to Kim (2009), jpeople with an approving attitude toward counterfeiting are more likely to purchase counterfeit products and vice versa. Budiman (2012) posited that, inherent factors - which tend to result from consumers' attitude have a positive influence on consumers' intention towards making counterfeit purchases. Conclusions drawn by Hidayat and Diwasasri (2013; Rahpeima et al., 2014) also reiterated that, the more constructive the attitude of consumers towards counterfeit products: The more their purchase intentions are strengthened. Deducing from the evidence above, the study concludes that:

H5: Consumer attitude towards the purchase of counterfeit items has a significant positive relationship with the intention to purchase counterfeit products

\section{Literature Review}

The literature comprised the theoretical literature as well the empirical literature. The theoretical literature presents the theory that was used in grounding the study while the empirical literature highlights on counterfeit and non-deceptive counterfeit, country of origin as well as consumers' reaction towards products from developed and developing countries.

\section{Signaling Theory}

Signaling theory was propounded by Spence (1973). The theory has been employed to selection situations that take place in a variety of disciplines-such as management (Connelly et al., 2011); sociology (Gambetta, 2009; Gambetta and Hamill, 2005); anthropology (Bird and Smith, 2005), as well as in marketing (Kirmani and Rao, 2000). It relies on the power of signals such as price, product warranty, information from other consumers and country of origin effect in considering information prior to a product purchase. In an attempt to better comprehend how consumers select or choose to purchase counterfeit products, the study presents an indicative elucidation of the signaling theory regarding how counterfeit products are purchased by consumers. 
In this study, signals that are given by other consumers are likely to influence others about a decision to purchase or not to purchase. The viewpoint of consumers on prices towards counterfeit products as well as the perceptual effect towards the origin of the counterfeit products are more likely to increase or decrease purchase intention - especially when consumers are signaled to do so by other consumers.

\section{Counterfeit}

Counterfeit is defined by Bian and Moutinho (2009) as products or brands that use a trademark - which is impossible to make a distinction from its registered trademark. According to Van Horen and Pieters, 2012:83) counterfeiting is the reproduction of a name, a logo of the original brand in taking advantage of the positive brand name. Wilcox et al. (2009) also termed counterfeit products as those which are prohibited to sell, usually for a cheaper price, but are lower priced replication of the actual product or brand while Lai and Zaichkowsky (1999:180) defined "a counterfeit as a $100 \%$ direct copy usually having inferior quality, although not always". The current study employed the definition by Wilcox et al. (2009) which defined counterfeit products as products that are illegal to sell, normally at cheaper prices and are a lower price imitation of the original product. The definition explains the term "counterfeit products" as used in the study.

\section{Non - Deceptive Counterfeiting}

Non-deceptive counterfeiting is defined as a condition where consumers are aware that they are buying counterfeit products or goods (Gentry et al., 2006; Wilcox et al., 2009). With the non - deceptive counterfeiting, consumers are conscious of the fact that they are purchasing the replicated products or the pirated products. According to Nia and Zaichkowsky (2000; Heidarzadeh and Taghipourian, 2012), non-deceptive counterfeiting is predominantly regular in luxury brand markets. The current study relied on non deceptive counterfeiting, where consumers go to the market place to deliberately purchase products they know are not the original products.

\section{Country of Origin}

There are diverse views about the explanation of the country of origin in consumer research. YongGu et al. (2016) defined Country of Origin (COO) effect as the effect on a buyer bearing in mind a product or service from another nation as a result of the stereotyping of that country and its products. Researchers or authors normally put them into different ideological pattern such as: Country of Assembly (COA); Country of Manufacturing (COM), Country of Design (COD) as well as country of brand (COB). According to Samiee (1994; Nebenzahl et al., 1997), country of design talks about the place where goods or products were designed - such ideology could sometimes be associated with country of origin by both customers and consumers. Usunier and Cestre (2007) also observed how country of manufacturing is acknowledged as the "Made in Country" and is comprehensively used to represent country of origin in academic research. In the current study, Usunier and Cestre's (2007) definition of the country of manufacturing was used as an operational definition for the study. Kotler and Armstrong (2001) opined that, the existence of halo effects has a strong association between products or goods and on its perceived country of manufacturing or the country of origin.

\section{Consumers Reactions: Developed and Developing Countries}

The effects of both price and country of origin differ in power depending on the level of development of countries. According to Usunier (1996) products that emanate from developing countries are believed to be risky and are also not valuable as compared to products from developed countries. Johansson and Nebenzahl (1986) posited that brand image of products tend to lessen, once the said products are manufactured in developing countries instead of developed countries. In the current study, the extant literature shows that products from developing countries are not patronised or sought after as often as products from the developed countries.

\section{Methodology}

\section{Research Approach and Design}

The study adopted a quantitative research approach and a descriptive research design. It employed a collection of quantitative data using structured questionnaires. According to Burns and Bush (2010:235), quantitative research, unlike qualitative research, is a suitable approach to use, when collecting data from a large number of respondents or participants. The approach was informed by the need to gather information from many respondents for hypothesis testing by means of statistical techniques.

\section{Target Population, Sampling and Size}

The target population for the study was counterfeit purchasers from the Kumasi Central Market and the Asafo Market - which are all in the Kumasi Metropolis. Owing to the nature of the study-regarding the sampling of counterfeit purchasers, only respondents who were buying products at that time and those who had already made purchases and were leaving the markets were sampled. The data collection started from December 2014 to January 2016 for the study. A non-probability sampling technique in the form of purposive sampling and snowballing sampling were used in selecting the respondents. The technique was chosen as there was no readily accessible list of consumer counterfeit purchasers to draw a random sample from. A total of two hundred and sixty five respondents was sampled for the study - a 
number that was suitable for the study's statistical software for the analysis.

\section{Measures and Assessment of the Research Variables}

A questionnaire using a five - point Likert scale was used to gather data for each construct of the research model. They were based on the extant literature as revealed by Mpinganjira (2014) that, drawing and adapting items already measured from previous studies in literature helped to enhance the validity of the succeeding measure. The measurement scale items were authenticated in preceding research with country of origin effect measure using a five - item scale adapted from Han (1990); Price measure employed a four item scale which was adapted from Mir et al. (2011); Purchase intention used a four item scale also adapted from Lee et al. (2012) while Attitude towards counterfeit purchase adapted five item scales from De Matos et al. (2007).

\section{Data Collection Method and Analysis}

As part of the data collection process, respondents were briefed on an individual basis to understand the motive behind the research - regarding a comparison of price and country of origin effect on their purchase pattern. The respondents were made aware that, responding to or the filling out of the questionnaires was not compulsory and that they could refuse to respond or not without any force or compulsion. Participants were personally approached by the researcher at various markets while others referred the researcher to other markets for the collection until the required number was reached. Questionnaires were completed by a number of the respondents and others were read to the respondents while the researcher ticked the appropriate responses. The researcher ensured that all the questions were answered.

The analysis of the data was done by cleaning and coding the responses on the questionnaires using a Statistical Package for Social Sciences (SPSS) and Excel software. SPSS was used for cross tabulation such as T Test statistic as well as the Kruskal - Wallis test while Partial Least Squares (Smart PLS) was used to analyse the hypothesised relationships of the study using Excel with "comma delimited".

\section{Reliability Assessment}

The reliability of the study was assessed using Cronbach alpha and composite reliability. The Cronbach's alpha $(\alpha)$ of all constructs was greater than 0.70 , and the Composite Reliability (CR) values were greater than 0.80 , indicating adequate internal consistency of the constructs (Hair et al., 2012).

\section{Convergent Validity}

Convergent validity simply explains the extent to which multiple items measuring the same concept are in agreement. Babin and Zikmund (2016:283) observed that, convergent validity depends on internal consistency that multiple measures converge on a dependable basis. According to Hair et al. (2013), for convergent validity to be evident in a study, the loadings for all items ought to be greater than 0.50 . In the current study, the $\mathrm{CR}$ and the AVE values all exceeded the recommended value. Therefore, the overall measurement model of the study established satisfactory convergent validity as shown in Table 1.

Table 1: Accuracy statistics

\begin{tabular}{|c|c|c|c|c|c|}
\hline \multicolumn{2}{|c|}{ Research constructs } & Cronbach alpha & $\mathrm{CR}$ & AVE & Factor loadings \\
\hline \multirow[t]{5}{*}{$\overline{\mathrm{AT}}$} & AT1 & 0.849 & 0.893 & 0.627 & 0.725 \\
\hline & AT2 & & & & 0.880 \\
\hline & AT3 & & & & 0.841 \\
\hline & AT4 & & & & 0.760 \\
\hline & AT5 & & & & 0.743 \\
\hline \multirow{5}{*}{$\mathrm{COO}$} & $\mathrm{COO} 1$ & 0.826 & 0.877 & 0.590 & 0.783 \\
\hline & $\mathrm{COO} 2$ & & & & 0.825 \\
\hline & $\mathrm{COO} 3$ & & & & 0.806 \\
\hline & $\mathrm{COO} 4$ & & & & 0.735 \\
\hline & $\mathrm{COO} 5$ & & & & 0.680 \\
\hline \multirow[t]{4}{*}{ PR } & PR1 & 0.932 & 0.951 & 0.830 & 0.883 \\
\hline & PR2 & & & & 0.906 \\
\hline & PR3 & & & & 0.909 \\
\hline & PR4 & & & & 0.945 \\
\hline \multirow[t]{4}{*}{$\mathrm{PN}$} & PN1 & 0.734 & 0.830 & 0.553 & 0.722 \\
\hline & PN2 & & & & 0.583 \\
\hline & PN3 & & & & 0.789 \\
\hline & PN4 & & & & 0.854 \\
\hline
\end{tabular}

Table 2: Inter - construct correlation matrix

\begin{tabular}{|c|c|c|c|c|}
\hline & AT & $\mathrm{COO}$ & PR & PI \\
\hline Attitude (AT) & 0.792 & & & \\
\hline Country of Origin (COO) & 0.640 & 0.768 & & \\
\hline Price effect (PR) & 0.578 & 0.706 & 0.911 & \\
\hline Purchase Intention (PI) & 0.720 & 0.575 & 0.496 & 0.744 \\
\hline
\end{tabular}




\section{Discriminant Validity}

Discriminant validity represents how unique or distinct a measure is: A scale should not correlate too highly with a measure of a different construct (Babin and Zikmund, 2016:283). The study employed Fornell and Larcker (1981) assessment is determining the discriminant validity.

As recommended by Fornell and Larcker (1981), discriminant validity is assessed by examining the AVE and squared correlations between the constructs. As illustrated in Table 2 all constructs met the discriminant validity as the AVE for each construct was greater than the squared correlation with the other constructs.

\section{Results}

\section{Findings from the Demographic Characteristics}

The data presented a moderately high number of respondents who were used to the purchase of counterfeit consumer products. A greater number of the counterfeit purchasers were females recording $64.9 \%$ while males constituted $35.1 \%$. The respondents' ages were skewed toward middle aged consumers between the ages of 31-40 years recording the highest; followed by 18-30 years with $22.6 \%$; $41-50$ years recorded $20.0 \%$ while respondents above the age of 50 years recorded the least with $8.7 \%$. In addition, the respondents in the study's sample were not exceedingly educated with half $50.2 \%$ having Middle School Leavers Certificate (MSLC)/Junior High School Certificate; with O/A - Level certificate recording 37.0\%; Diplomas recording $10.6 \%$ while degrees recorded the least with $2.3 \%$. A greater part of the respondents were married. They represented $47.5 \%$; followed by single respondents representing $43.8 \%$ while respondents who had separated from marriages or were divorced constituted the least with $8.7 \%$. The main implication is that, the more people become educated the less they involve themselves into the purchase of counterfeit products.

Table 3. explains a significant difference in responses between respondents' gender and their perception on country of origin effect being significant while the other variables were not significant.

An independent sample t-test was conducted to compare country of origin scores for males and females respondents of the study. There was a significant difference in scores for males $(\mathrm{M}=3.4677$, $\mathrm{SD}=0.63334)$ and females $(\mathrm{M}=3.6555, \mathrm{SD}=$ $0.73111) ; \mathrm{t}(265)=263 ; \mathrm{p}=0.038$, two - tailed. The magnitude of the difference showed from the mean values revealed that, female respondents reacted to the purchase of counterfeit using country of origin effect more than their male counterparts. It demonstrated a significant difference in views on country of origin effect between male and female purchasers of counterfeit consumer products.

\section{Difference in Country of Origin effects Across Age Levels}

The difference in the influence of country of origin effects on the respondents' age levels was estimated using the Kruskal - Wallis Test statistics as shown in Table 5.

Table 5 depicts the level of significance with 0.008 which is less than the recommended threshold of $\mathrm{p}<0.05$; demonstrating the significance level of the relationship between country of origin effects on the various age levels.

The results of the Kruskal - Wallis Test revealed a statistically significant difference in country of origin effects on the age groups : $\mathrm{N}=265,18-30$ years, $31-40$ yrs, $41-50$ years and 51 years and above; $X 2(3, n=265)$ $=11.826, \mathrm{p}=0.008$. The mean rank values revealed that, respondents between the ages of $18-30$ years recorded the highest with 148.68; followed by $41-50$ years with $134.35 ; 31-40$ years recorded 133.70 while 51 and above years recorded the least with 85.07. It was clear from the findings that, when the early years' figures are put together, their total mean rank become 282.38 and in percentage terms its represents $56 \%$. It therefore demonstrated how the youth were becoming attached to the purchase of counterfeit products due to country of origin effect as shown in Fig 1.

\section{Goodness of Fit}

The study's goodness of fit statistics (GOF) was calculated using a formula by Tenenhaus et al. (2005), where the averages of the Average Variance Extracted (AVE) was first multiplied by the averages of the $\mathrm{R}^{2}$ values, after which the multiplied value or the result was squared to determine the model fit.

Table 4. presents an independent sample $\mathrm{t}$ - test that was conducted to compare country of origin scores for males and females respondents of the study. There was a significant difference in scores for males $(\mathrm{M}=3.4677$, $\mathrm{SD}=0.63334)$ and females $(\mathrm{M}=3.6555, \mathrm{SD}=0.73111)$; $\mathrm{t}(265)=263 ; \mathrm{p}=0.038$, two - tailed. The magnitude of the difference showed from the mean values revealed that, female respondents reacted to the purchase of counterfeit using country of origin effect than their male counterpart.

Table 3: A T - test statistic between gender and country of origin

\begin{tabular}{llllll}
\hline & & & & Std. & Std. \\
& Gender & no & Mean & deviation & 0.06567 \\
\hline Country of origin & Male & 93 & 3.4677 & 0.63334 & 0.05575 \\
& Female & 172 & 3.6555 & 0.73111 & 0.000 \\
\hline
\end{tabular}




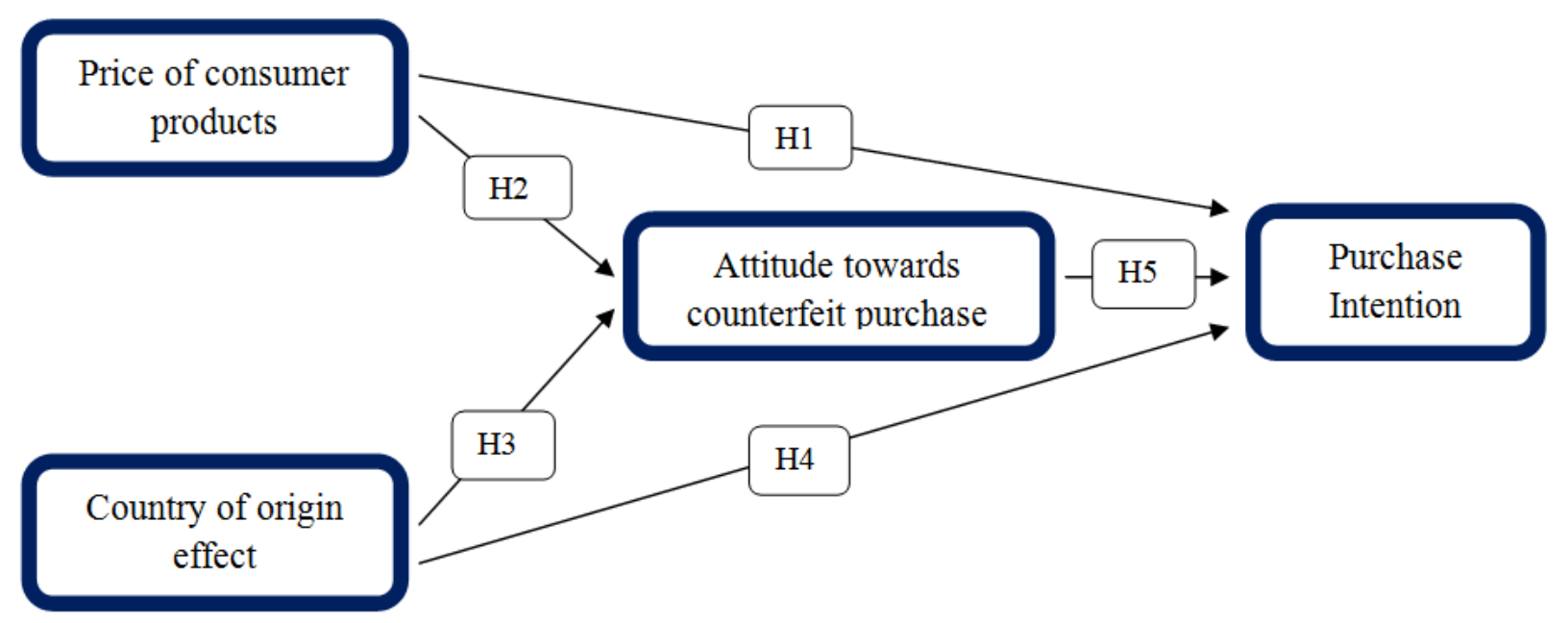

Fig. 1: Conceptual model of the study. Source: Author's construction (2017)

Table 4: Independent sample $\mathrm{t}$ - test

\begin{tabular}{lllllll}
\hline & & $\mathrm{F}$ & $\mathrm{Sig}$ & $\mathrm{t}$ & $\mathrm{Df}$ & Sig. (2-tailed) \\
\hline Country of origin effect & Equal Variances assumed & 2.482 & 0.116 & -2.089 & 263.00 & 0.038 \\
& Equal variances not assumed & & & -2.180 & 212.877 & 0.030 \\
\hline
\end{tabular}

Table 5: Kruskal-wallis test statistics of country of origin on age level

\begin{tabular}{lr}
\hline Chi -Square & 11.826 \\
Df & 3.000 \\
Asymp.sig & 0.008 \\
\hline
\end{tabular}

It demonstrated a significant difference in views on country of origin effect between male and female purchasers of counterfeit consumer products.

The calculated Goodness of Fit (GoF) was 0.565 , which exceeded the threshold of $\mathrm{GoF}>0.36$ recommended by Wetzels et al. (2009). Thus, the study therefore concluded that the research model had a better fit than that model.

$$
\begin{aligned}
\mathrm{GoF} & =\sqrt{ } \mathrm{AVE} * \mathrm{R}^{2} \\
& =\sqrt{ } 0.65 * 0.491 \\
& =\sqrt{ } 0.31915 \\
& =0.565
\end{aligned}
$$

\section{Hypothesis Analysis}

Table 7 and Figure 2. present the hypothesis analysis. The study employed path analysis to test the five hypotheses. The $\mathrm{R}^{2}$ value of 0.441 for attitudes toward counterfeit consumer products indicated that, $44.1 \%$ of the variance was explained by price factors and country of origin factors. The $\mathrm{R}^{2}$ value of 0.541 for consumer purchase intentions toward counterfeit of products suggested that, $54.1 \%$ of the variance was explained by consumer attitudes toward counterfeit of consumer products in the metropolis. Bootstrapping was applied to validate the results of the hypotheses, with 300 bootstrap samples selected for a one-tailed test based on critical t values of 1.65 (significance level 5\%) and 2.33 (significance level 1\%) (Hair et al., 2013). The hypothesis results presented in Table 7 showed that, the price factor, the country of origin effect with values $(\beta=$ $1.977, \mathrm{p}<0.05)$ and $(\beta=4.022, \mathrm{p}<0.05)$ respectively have significant positive influence on consumer attitudes toward counterfeit consumer products. There was also a significant positive relationship between attitudes towards counterfeit purchase, country of origin effect on consumer purchase intention with $(\beta=6.739, \mathrm{p}<0.05)$ and $(\beta=1.652, \mathrm{p}<0.05)$.However, the intention to test whether price effect has an influence on consumer purchase intention of counterfeit products was positive but not significant. Thus, $H 1$ was not supported.

Table 5 and 6 . describe the level of significance with 0.008 which is less than the recommended threshold of $\mathrm{p}$ $<0.05$; demonstrating the significance level of the relationship between country of origin effects on the various age levels.

The results of the Kruskal - Wallis Test revealed a statistically significance difference in country of origin effects on the age groups : $\mathrm{n}=265,18-30$ years, 31 $40 \mathrm{yrs}, 41-50$ years and 51 years and above; X2 $(3, \mathrm{n}=$ $265)=11.826, p=0.008$. The mean rank values revealed that, respondents between the ages of $18-30$ years recorded the highest with 148.68 ; followed by 41 - 50 years with $134.35 ; 31$ - 40 years recorded 133.70 while 51 and above years recorded the least with 85.07. 
Table 6: Kruskal-wallis testing of ranks

\begin{tabular}{llll}
\hline & Age & Number & Mean rank \\
\hline Country of origin effect (COO) & $18-30$ & 60 & 148.68 \\
& $31-40$ & 129 & 133.70 \\
& $41-50$ & 53 & 134.35 \\
& 51 and above & 23 & 85.07 \\
\hline
\end{tabular}

Table 7: Results of the structural equation model analysis

\begin{tabular}{llllll}
\hline Study's hypothesis & Hypothesis & Path coefficients & T-statistics & P-values & Supported / rejected \\
\hline $\mathrm{PR} \rightarrow$ PI & H1 & 0.032 & 0.298 & 0.766 & Rejected \\
$\mathrm{PR} \rightarrow$ AT & H2 & 0.252 & 1.977 & $0.039^{* *}$ & Supported \\
COO $\rightarrow$ AT & H3 & 0.462 & 4.022 & $0.000^{* * *}$ & Supported \\
COO $\rightarrow$ PI & H4 & 0.175 & 1.652 & $0.048^{* *}$ & Supported \\
AT $\rightarrow$ PI & H5 & 0.590 & 6.739 & $0.000^{* * *}$ & Supported \\
\hline
\end{tabular}

Note: $\mathrm{PR}=$ Price effect; AT $=$ Attitude towards counterfeit purchase; $\mathrm{COO}=$ Country of Origin effect while PI = Purchase Intention. $\mathrm{p}<0.05$ and $\mathrm{p}<0.01$.

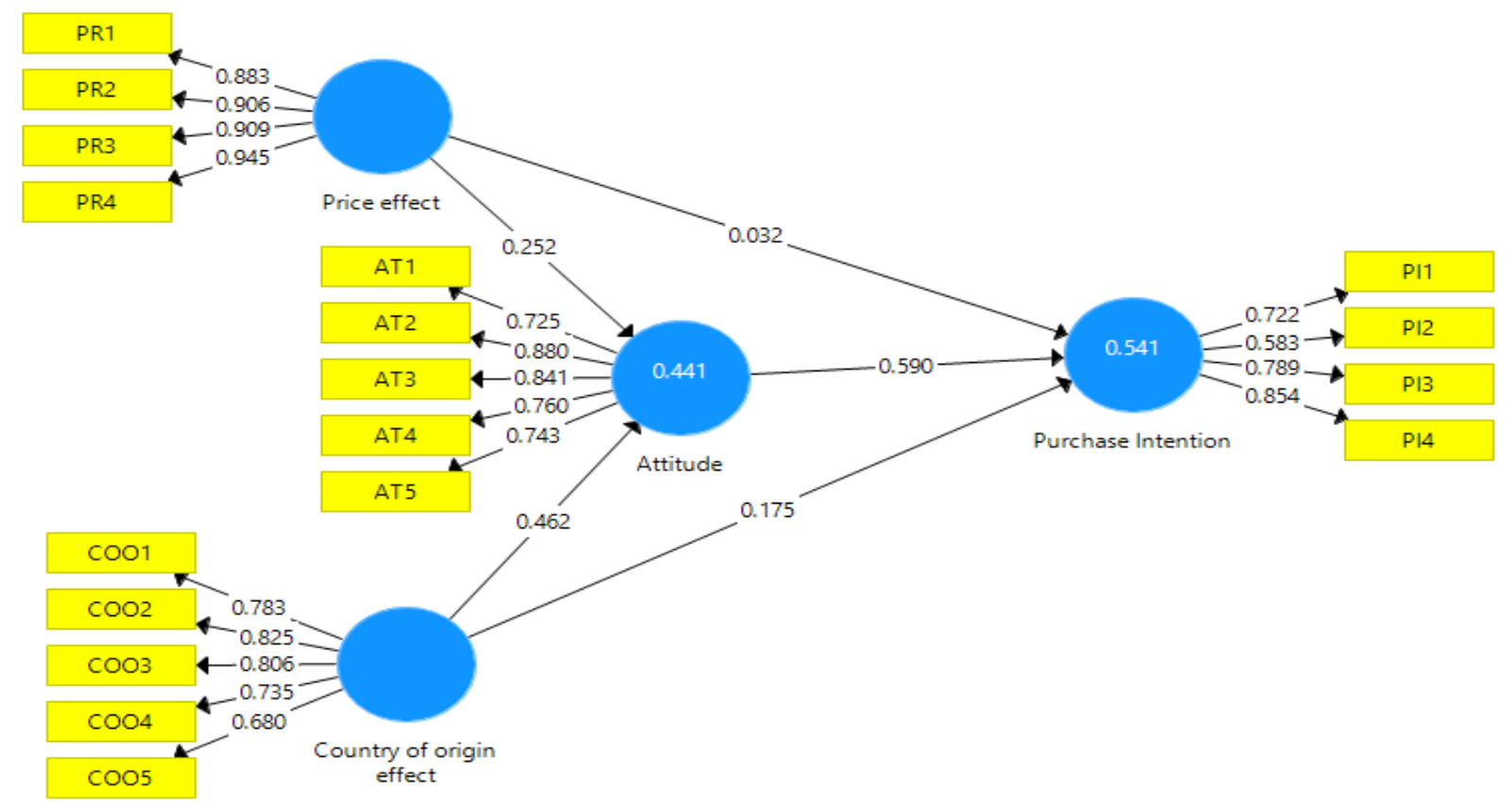

Fig. 2: The structural model of the study. Note: $P R=$ Price effect; AT = Attitude towards counterfeit purchase; COO = Country of Origin effect while PI $=$ Purchase Intention

It was clear from the findings that, when the early years' figures are put together, their total mean rank become 282.38 and in percentage terms its represents $56 \%$. It therefore demonstrated how the youth were becoming attached to the purchase of counterfeit products due to country of origin effect.

\section{Findings and Discussions}

Previous research on counterfeiting acknowledged product variables such as price, vendor characteristics, social, demographic and psychographic variables as determinants of consumers' intention to purchase counterfeit products (Eisend and Schuchert-Guler, 2006). The study compared the effects of both price and country of origin on the attitude of consumers as well as their intent in making purchase decisions. Five hypotheses were outlined for the test analysis. First, it was evident from the study that, country of origin effect had a greater influence on the attitude of consumers towards counterfeit purchases than its price effect. The coefficient value of $(0.462)$ which was greater than (0.252), which explained that consumer's attitude towards counterfeit purchase through the country of origin of the said products was higher than the price charge for the same consumer products. The findings of 
the study were consistent with Phau et al. (2009) who opined that, the purchase of counterfeit products for reasons of price situation was very minimal. According to Bian and Moutinho (2009), price determinants were not the only factors that have effects on consumer attitudes towards counterfeit. In addition, the study findings also made it apparent that, country of origin effects also had a greater influence on consumers' purchase intention. The coefficients or the loadings in the path analysis revealed $(0.175)$ for country of origin effects while price effect on purchase intention was (0.032) demonstrating a strong case for country of origin effect factor being stronger than price effect on consumers' intent in buying counterfeit products. Phau and Teah (2009) as well as Tang et al. (2014), observed that country of origin effects have greater influence on consumers' purchase intention. Finally, attitude towards counterfeit purchase intention was observed to be strong among the respondents, their relationship revealed a value of (0.590) which was higher than all the hypothesised relationships. The findings were in consonance with previous studies by Harun et al. (2012), Hidayat and Diwasasri (2013) as well as Rahpeima et al. (2014). The study then concluded that country of origin effect has a greater influence on both attitude and consumer purchase intention than price of the counterfeit products.

\section{Theoretical Contribution}

This study makes significant contributions to counterfeit consumption and consumer behaviour literature. First, the study contributes to the academic literature on the generic relevance of comparing country of origin effect and price factor in a single study to assess their effects on attitude and intention to make purchase of counterfeit products in a developing country.

In building on preceding studies, new consumer stimulus for counterfeit consumption is identifiedspecifically, country of origin effect being influential on consumers' in making purchase other than price factor. It also adds to further understanding on the use of signalling theory on price and country of origin. The study has demonstrated the effectiveness of the Signalling theory by Spence (1973) in a situation where users of consumer products have a greater influence on other consumers through the use of signals such as country of origin, packaging, advertising towards the influence of purchases other than the actual price of the product.

\section{Managerial Contribution}

The new insight offered by the study on country of origin (COO) effect in the counterfeit market is expected to support marketers and strategic decision makers of manufacturers that are planning to enter the consumer product market business or those that are already in that market. In the event of entering the foreign market for import of consumer products, marketers or the local manufacturers ought to be cautious of its pricing of imported products and the positioning strategies employed in the process of selling the products. The findings revealed that, country of origin effect significantly influences attitude and intentions towards counterfeit purchase. Related products with different country of origin labels are seen significantly different by consumers and therefore marketers ought to intensify comparative advertising activities in creating awareness on their products attributes to both prospective and potential consumers. Marketing strategies also need to be structured to create awareness on the harmful effect of purchasing counterfeit products.

\section{Contribution to Policy}

The various government institutions in Africa and the media could share insights of losses and damages caused by the purchase of counterfeit products to the public. Persistent attempt ought to be intensified by the various manufacturing organisations to limit the demand for counterfeit products - apart from the supply side control systems. This could be done by the Food and Drugs Authority in Ghana so as to curb the import of counterfeit products from the western countries.

\section{Conclusion}

A profound understanding of how consumer counterfeit purchasers perceive and react to counterfeit consumer products using price and country of origin was more likely to clarify the psychological process of signalling theory as important for researchers, practitioners and policy makers. The purpose of the study was to compare the views of consumer counterfeit purchasers on price and country of origin (COO) towards attitude and intention to make purchase decisions from a developing country - Ghana. This research expressly focused on deliberate counterfeit purchasers from a non deceptive counterfeiting perspective. The study concludes that, country of origin effect is the strongest extrinsic indication; counterfeit purchasers relied heavily on their purchase decisions other than the price factor. One reason for the manifestation of counterfeit purchase was observed from the cultural perspective - where counterfeit purchasers clinch to products from the United States, the United Kingdom, Canada, Australia and other Western countries - even if the products are known to be harmful but disregard the locally made products even if they are of high quality. The undue regard for products and items from the western countries is seriously promoting the conscious purchase of counterfeit consumer products. 


\section{Limitations of the Study}

Although the study offers significant contributions to understand the comparison between price and country of origin effect on consumer counterfeit purchase in the academia, practitioners and policy initiative. However, it has some limitations. First and foremost, the study relates to the fact that, it was based on a sample of purchasers from a limited geographical area, namely Kumasi. Secondly, the sample was drawn through nonprobability sampling techniques-which makes it clear that, the study's findings may not be generalised to the broader population of counterfeit purchasers or buyers in Ghana. Further studies are needed to widen its scope for generalisation to be made.

\section{Acknowledgement}

The author is indebted to the anonymous reviewers and the editor for their productive insights and suggestions.

\section{Ethics}

The study's contents are the standpoint of the author and not that of the journal publishers. The paper has not been published elsewhere or is it being deliberated for publication in any other journal.

\section{References}

Ansah, M.O. 2017. Non - price factors on consumer counterfeit Products purchase. Proceedings of the 11th International Business Conference, Dar es Salam, Tanzania.

Awada, L. and A. Yiannaka, 2012. Consumer perceptions and the effects of country of origin labeling on purchasing decisions and welfare. Food Policy, 37: 21-30. DOI: 10.1016/j.foodpol.2011.10.004

Babin, J.B. and W. Zikmund, 2016. Exploring marketing Research.11th Edn., Cengage Learning, Hampshire, England, ISBN-10: 1305843436, pp: 656.

Bamossy, G. and D.L. Scammon, 1985. Product counterfeiting: Consumers and Manufacturers Beware. In: NA-Advances in Consumer Research, Hirschman, E.C. and M.B. Holbro (Eds.), Association for Consumer Research, Provo, UT: pp: 334-339.

Bian, X. and L. Moutinho, 2009. An investigation of determinants of counterfeit purchase consideration. J. Bus. Res., 62: 368-378.

DOI: 10.1016/j.jbusres.2008.05.012

Bian, X. and L. Moutinho, 2011. Counterfeits and branded products: Effects of counterfeit wnership. J. Product Brand Manage., 20: 379-393.

DOI: $10.1108 / 10610421111157900$
Bian, X., S. Haque and A. Smith, 2015. Social power, product conspicuousness and the demand for luxury brand counterfeit products. Br. J. Soc. Psychol., 54: 37-54. DOI: 10.1111/bjso. 12073

Bird, R., B. and E.A. Smith, 2005. Signaling Theory, strategic interaction and symbolic capital. Curr. Anthropol., 46: 221-248. DOI: 10.1086/427115

Bloch, P.H., R.F. Bush and L. Campbell, 1993. Consumer accomplices in product counterfeiting: A demand side investigation. J. Consumer Market., 10: 27-36. DOI: 10.1108/07363769310047374

Budiman, S., 2012. Analysis of consumer attitudes to purchase intentions of counterfeiting bag product in Indonesia. Int. J. Manage., Econ. Soc. Sci., 1: 1-12.

Burns, A. and R. Bush, 2010. Marketing Research. 6th Edn., Prentice Hall, Upper Saddle River, N.J., ISBN-10: 0137135998, pp: 695.

Chakraborty, G., A.T. Allred and T. Bristol, 1996. Exploring consumers' evaluations of counterfeits: The roles of country of origin and ethnocentrism. Adv. Consumer. Res., 23: 379-384.

Chaoa, P., 1998. Impact of country-of-origin dimensions on product quality and design quality perceptions. J. Bus. Res., 42: 1-6. DOI: 10.1016/S0148-2963(97)00129-X

Chen, J., L. Teng, S. Liu and H. Zhu, 2015. Anticipating regret and consumers' preferences for counterfeit luxury products. J. Bus. Res., 68: 507-515. DOI: $10.1016 /$ j.jbusres.2014.09.012

Cheng, S.I., F.H. Hui and L.T. Cam, 2011. Examining customer purchase intentions for counterfeit products based on a modified theory of planned behaviour. Int. J. Humanities Soc. Sci., 1: 278-284.

Chia-Lin, H., C. Chi-Ya and Y. Chutinart, 2017. Exploring purchase intention of green skincare products using the theory of planned behavior: Testing the moderating effects of country of origin and price sensitivity. J. Retailing Cons. Serv., 34: 145-152. DOI: 10.1016/j.jretconser.2016.10.006

Chiu, W. and H.K. Leng, 2016. Consumers' intention to purchase counterfeit sporting goods in Singapore and Taiwan. Asia Pac. J. Mark. Logist., 28: 23-36. DOI: 10.1108/APJML-02-2015-0031

Connelly, B.L., S.T. Certo and R.D. Ireland et al., 2011. Signaling theory: A review and assessment. J. Management, 37: 39-67. DOI: $10.1177 / 0149206310388419$

Cordell, V., N. Wongtada and R.L. Kieschnick. Jr, 1996. Counterfeit purchase intentions: Role of lawfulness attitudes and product traits as determinants. J. Bus. Res., 35: 41-53. DOI: 10.1016/0148-2963(95)00009-7

De Matos, C.A., C.T. Ituassu and C.A. Vargas, 2007. Consumer attitudes toward counterfeits: A review and extension. J. Consumer Marketing, 24: 36-47. DOI: $10.1108 / 07363760710720975$ 
Eisend, M. and P. Schuchert-Guler, 2006. Explaining counterfeit purchase: A review and preview. Academy Marketing Sci. Rev., 12: 1-26.

Fornell, C. and D. F. Larcker, 1981. Evaluating structural equation models with unobservable variables and measurement error. J. Marketing Res., 18: $39-50$. DOI: $10.2307 / 3151312$

Gambetta, D and H. Hamill, 2005. Streetwise: How Taxi Drivers Establish Customer's Trustworthiness. New York: Russell Sage Foundation, pp: 264, ISBN-10. 1610442350

Gambetta, D., 2009. Codes of the Underworld: How Criminals Communicate. 1st Edn., Princeton University Press, ISNB-10: 0691119376, pp: 336.

Gentry, J.W., P. Sanjay and C.J. Schultz II, 2006. The Effects of counterfeiting on consumer search. J. Consumer Behaviour, 5: 245-256.

DOI: $10.1002 /$ cb. 176

Gentry, J.W., P. Sanjay, C. Shultz and S. Commuri, 2001. How now Ralph Lauren? The separation of brand and product in a counterfeit culture. Adv. Consumer Res., 28: 258-265.

Ghazali, M., M.S. Othman, A.Z. Yahya and M.S. Ibrahim, 2008. Products and country of origin effects: The Malaysian consumers' perception. Int. Rev. Bus. Res. Papers, 4: 191-102.

Godey, B., D. Pederzoli, G. Aiello, R. Donvito and P. Chan et al., 2012. Brand and country-of-origin effect on consumers' decision to purchase luxury products. J. Bus. Res., 65: 1461-1470.

DOI: $10.1016 /$ j.jbusres.2011.10.012

Hair, J.F.M., T. Sarstedt, M. Pieper and C.M. Ringle, 2012. The use of partial least squares structural equation modeling in strategic management research: A review of past practices and recommendations for future applications. Long Range Planning, 45: 320-340.

Hair, J.F., Jr, G. T.M. Hult, C. Ringle and M. Sarstedt, 2013. A PRIMER on Partial Least Squares Structural Equation Modeling (PLS-SEM). Thousand Oaks: SAGE, ISBN-10: 1483321452, pp: 328.

Han, C., 1990. Testing the role of country image in consumer choice behavior. Eur. J. Marketing, 24: 24-40. DOI: 10.1108/EUM0000000000609

Han, H., L.T. Hsu and C. Sheu, 2010. Application of the theory of planned behavior to green hotel choice: Testing the effect of environmental friendly activities. Tour. Manag., 31: 325-334.

DOI: 10.1016/j.tourman.2009.03.013

Harvey, P.J. and W.D Walls, 2003. Laboratory Markets in counterfeit goods: Hong Kong versus Las Vegas Applied Economics Lett., 10: 883-887.

DOI: $10.1080 / 1350485032000155431$
Heidarzadeh, H.K. and M.J. Taghipourian, 2012. Attitudes toward Counterfeit products and generation differentia. Res. J. Applied Sci. Eng. Technology 4: 1147-1154.

Hidayat, A. and A.H.A. Diwasasri, 2013. Factors influencing attitudes and intention to purchase counterfeit luxury brands among Indonesian consumers. Int. J. Marketing Studies, 5: 143-151. DOI: $10.5539 /$ ijms.v5n4p143

IACC, 2014. Counterfeiting statistics. http://www.iacc.org/counterfeiting-statistics

Insch, G.S. and J.B. McBride, 2004. The impact of country-of-origin cues on consumer perceptions of product quality: A bi national test of the decomposed country-of-origin construct. J. Bus. Res., 57: 256-265. DOI: $10.1016 / \mathrm{S} 0148-2963(02) 00323-5$

Jaffe, E.D. and I.D. Nebenzahl, 2001. National Image and Competitive Advantage: The Theory and Practice of Place Branding. Copenhagen: Copenhagen Business School Press, ISBN-10: 8716135164, pp: 186,

Jiang, L. and V. Cova, 2012. Love for luxury, preference for counterfeits-A qualitative Study in counterfeit luxury consumption in China. Int. J. Mark. Stud. 4: 1-6. DOI: 10.5539/ijms.v4n6p1

Johansson, J.K. and I.D. Nebenzahl, 1986. Multinational production: Effect on brand value. J. Int. Bus. Stud., 17: 101-126. DOI: 10.1057/palgrave.jibs. 8490861

Kim, J.E., 2009. The influence of moral emotions young adults' moral decision making: A cross cultural examination. A dissertation submitted to the Faculty of the Graduate School of the University of Minnesota, Minneapolis, MN.

Kirmani, A. and A.R. Rao, 2000. No Pain, No Gain: A critical review of the literature on signaling unobservable product quality. J. Mark., 64: 66-79. DOI: $10.1509 /$ jmkg.64.2.66.18000

Klaus-Peter, W., N. Hennigs and C. Klarmann, 2012. Luxury consumption in the trade-off between genuine and counterfeit goods: What are the consumers' underlying motives and value-based drivers? J. Brand Management, 19: 544-566. DOI: $10.1057 / \mathrm{bm} .2012 .10$

Knight, G.A. and R.J. Calantone, 2000. A flexible model of consumer country-of-origin perceptions: A crosscultural investigation. Int. Mark. Rev., 17: 127-145. DOI: $10.1108 / 02651330010322615$

Kotler, P. and G. Armstrong, 2001. Principles of Marketing. 9th Edn., Prentice Hall, ISBN-10: 0130263125, pp: 785.

Lai, K.K.Y. and J.L. Zaichkowsky, 1999. Brand imitation: Do the Chinese have different views? Asia Pacific J. Manage., 16: 179-192. DOI: $10.1023 / \mathrm{A}: 1015482707900$ 
Laroche, M., N. Papadopoulos, L.A. Heslop and M. Mourali, 2005. The influence of country image structure on consumer evaluations of foreign products. Int. Mark. Rev., 22: 196-115.

DOI: $10.1108 / 02651330510581190$

Lee, B.K., 2005. The effects of product knowledge on product memory and evaluation in competitive versus non-competitive ad context: Within the itemspecific and relational processing framework. $\mathrm{PhD}$ of Philosophy, Faculty of the Graduate School, the University of Texas at Austin. USA.

Lee, W., L. Xiong and C. Hu, 2012. The effect of Facebook users' arousal and valence on intention to go to the festival: Applying an extension of the technology acceptance model. Int. J. Hospitality Management, 31: 819-827.

Lin, L.Y. and C.S. Chen, 2006. The influence of the country-of-origin image, product knowledge and product involvement on consumer purchase decisions: An empirical study of insurance and catering services in Taiwan. J. Consumer Mark., 23: 248-265. DOI: 10.1108/07363760610681655

Mir, I.A., M. Rizwan and F. Saboor, 2011. Pricing and Accessibility impact on young consumer attitude towards non-deceptive counterfeit and their purchase intention: A case of Pakistani mobile 38 phone market. Actual Problems Eco., 4: 406-414.

Mitchell, A.A. and J.C. Olson, 1981. Are product beliefs the only mediator of advertising effect on brand attitude? J. Mark. Res., 18: 318-332.

DOI: $10.2307 / 3150973$

Mpinganjira, M., 2014. The influence of online store interactivity on customers' shopping experience: An empirical investigation. J. Contem. Management, 11: 593-612. DOI: 10.1016/j.im.2011.08.001

Nebenzahl, I.D., E.D. Jaffe and S. Lampert, 1997. Towards a theory of country image effect on product evaluation. Manage. Int. Rev., 37: 27-49.

Nebenzahl, I.D. and E. D. Jaffe, 1996. Measuring the joint effect of brand and country image in consumer evaluation of global products. Int. Marketing Rev., 13: 5-22.

Nia, A. and J.L. Zaichkowsky, 2000. Do counterfeits devalue the ownership of luxury Brands? J. Product Brand Managent., 9: 485-497. DOI: $10.1108 / 10610420010351402$

Nwankwo, S., N. Hamelin and M. Khaled, 2014. Consumervalues, motivation and purchase intention for luxury goods. J. Retail. Consum. Serv., 21: 735-744. DOI: 10.1016/j.jretconser.2014.05.003

Phau, I., M. Sequeira and S. Dix, 2009. Consumers' willingness to knowingly purchase counterfeit products. J. Direct Mark. An Int., 3: 262-281. DOI: $10.1108 / 17505930911000865$
Phau, I.D. and M. Teah, 2009. Targeting buyers of counterfeit of luxury brands: A study on attitudes of Singaporean consumers. J. Targeting Measurement Ana. Mark., 17: 3-15. DOI: 10.1057/jt.2008.25

Poddar, A., J. Foreman, S. Banerjee and P.S. Ellen, 2012. Exploring the robin hood effect: Moral profiteering motives for purchasing counterfeit products. J. Bus. Res., 65: 1500-1506.

DOI: 10.1016/j.jbusres.2011.10.017

Rahpeima, A., H. Vazifedost, K.H. Hanzaee and H. Saeednia, 2014. Attitudes toward counterfeit products and counterfeit purchase intention in non deceptive counterfeiting: Role of conspicuous consumption, integrity and personal gratification. WALIA J., 30: 59-66.

Rezvani, S., G.J. Dehkordi, M.S. Rahman, F. Fouladivanda and M. Habibi et al., 2012. A conceptual study on the country of origin effect on consumer purchase intention. Asian Soc. Sci., 8: 12. DOI: $10.5539 /$ ass.v8n12p205

Roth, K. and A. Diamantopoulos, 2009. Advancing the country image construct. J. Bus. Res., 62: 726-740. DOI: 10.1016/j.jbusres.2008.05.014

Rutter, J. and J. Bryce, 2008. The consumption of counterfeit Goods: 'Here be Pirates? Sociology, 42: 1146-1164. DOI: 10.1177/0038038508096938

Sahin, A.D. and O. Atilgan, 2011. Analyzing factor that drive consumers to purchase counterfeits of luxury Branded product. J. Am. Academy Bus. Cambridge. 17: 283-292.

Samiee, S., 1994. Customer evaluation of products in a global market. J. Int. Bus. Stud., 25: 579-604. DOI: $10.1057 /$ palgrave.jibs. 8490213

Spence, M., 1973. Job market signaling. Quarterly J. Econ., 87: 355-374. DOI: 10.2307/1882010

Staake, T., F. Thiesse and E. Fleisch, 2009. The emergence of counterfeit trade: A literature review. Eur. J. Mark., 43: 320-349.

DOI: 10.1108/03090560910935451

Stöttinger, B. and E. Penz, 2015. Concurrent ownership of brands and counterfeits: Conceptualization and temporal transformation from a consume perspective. Psychol. Mark., 32: 373-391. DOI: 10.1002/mar.20786

Stumpf, S.A. and P.E. Chaudhry, 2011. Consumer complicity with counterfeit products. J. Onsumer Mark., 28: 139-151.

DOI: $10.1108 / 07363761111115980$

Tang, F., V. Tian and J. Zaichkowsky, 2014. Understanding counterfeit consumption. Asia Pac. J. Mark. Logist., 26: 4-20.

DOI: 10.1108/APJML-11-2012-0121

Tenenhaus, M., V.E. Vinzi, Y.M. Chatelin and C. Lauro, 2005. PLS path modeling. Comput. Stat. Data Ana., 48: 159-205. DOI: 10.1016/j.csda.2004.03.005 
Usunier, J.C. and G. Cestre, 2007. Product ethnicity: Revisiting the match between products and countries'. J. Int. Mark., 15: 32-72. DOI: $10.1509 /$ jimk.15.3.32

Usunier, J.C., 1996. Marketing Across Cultures. 2nd Edn., Prentice Hall, New York, ISBN-10: 0132361752, pp: 576.

Van Horen, F. and R.R. Pieters, 2012. When highsimilarity copycats lose and moderate similarity copycats gain: The impact of comparative evaluation. J. Mark. Res., 49: 83-91. DOI: $10.1509 /$ jmr.08.0405

Wetzels, M., G. Odekerken-Schröder and C. Van Oppen, 2009. Using PLS path modeling for assessing hierarchical construct models: Guidelines and empirical illustration. Manage. Inform. Syst. Q., 33: 177-195.
Wilcox, K., H.M. Kim and S. Sen, 2009. Why do consumers buy counterfeit luxury brands? J. Mark. Res., 46: 247-259.

DOI: $10.1509 / \mathrm{jmkr} .46 .2 .247$

YongGu, S., Y.H. Jung and D.G. Davies, 2016. Cultural appropriation and the country of origin effect. J. Bus. Res., 69: 2721-2730. DOI: $10.1016 /$ j.jbusres.2015.11.007

Zeugner-Roth, K.P. and A. Diamantopoulos, 2010. Advancing the country image construct: Reply to Samiee's (2009) commentary. J. Bus. Res., 63: 446-449. DOI: 10.1016/j.jbusres.2009.09.009 